International Journal of Arts and Humanities Studies (IJAHS)

ISSN: $2754-4311$

DOI: 10.32996/ijahs

Journal Homepage: www.al-kindipublisher.com/index.php/ijahs

\title{
The Impact of Covid-19 on Online Learning in K12 Indonesian Schools: Macro, Meso, and Micro Levels
}

\author{
Karisma Erikson Tarigan ${ }^{1} \square$ and Margaret Stevani ${ }^{2}$ \\ ${ }^{12}$ Fakultas Pendidikan Bahasa Inggris, Universitas Katolik Santo Thomas Sumatera Utara, Indonesia \\ $\square$ Corresponding Author: Karisma Erikson Tarigan, E-mail: erick_tarigan2006@yahoo.com
}

ARTICLE INFO

Received: 02 September 2021

Accepted: 11 October 2021

Published: 24 October 2021

DOI: 10.32996/ijahs.2021.1.1.4

\section{KEYWORDS}

K12 Indonesian Schools, Online Learning, Covid-19, Macro, Meso, Micro Levels.

\section{ABSTRACT}

The Covid-19 had changed the causal relationship of the responses about the effective planning of competency, academic, mental health, and technology usage from government, teachers, and students in Indonesian schools. The primary objective in this research was to investigate the problems, the solutions, and the impact of macro level (policies, strategy, and official curricula from Indonesian government), meso level (Indonesian teachers in K12 schools), and micro level (Indonesian students K12 schools) during COVID-19 pandemic and Indonesian online learning policy by comparing K12 Indonesian schools. The study was a qualitative method of the phenomenological approach. The sample of this study was 272 teachers and 3988 students of Indonesian K-12 schools in North Sumatera, Indonesia. The data was obtained through an online survey by using google form and Circular Letters from the Indonesian government by using newspapers. The findings proved that Indonesian teachers and students agreed with the effectiveness of online learning training programs and activities to improve competency and academic progress even though there were some barriers to technology usage. All these findings proved that the transitions of macro, meso, and micro levels in institutional to society-wide level had demonstrated digital pedagogy and students' learning decision-making process changed the organization of Indonesian school management.

\section{Introduction}

The Coronavirus Disease 2019 (COVID-19) pandemic situation is an emergent global threat and Indonesia entered a country with an emergency status with the number of confirmed positive cases of COVID-19 reached to 1,528 cases in March 2020 (Djalante et al, 2020). Due to the pandemic situation, the Indonesian government issued several policies that involved various roles of government institutions. One of them was Indonesian Government Regulation Number 6 of 2020 concerning Large-Scale Social Restrictions which is supported by Regulation of the Minister of Health Number 9 of 2020 concerning Guidelines for Large-Scale Social Restrictions in the Framework of Acceleration Handling of Covid-19. The activities forced by Kemendikbud or the Ministry of Education and Culture (MoEC) Indonesia were to conduct distance learning by using online platforms and students should follow self-directed learning guided by their parents (Abidah et al, 2020; Azhari \& Fajri, 2020).

Pedagogical education activities involved sets of goals, materials, activities, and people in the aspects of collaborative teaching and learning. The levels in these circles were the students and their families (micro level), the teachers, education, and training courses (meso level), and government policy (macro-level). These three components characterized the meso level as the important structure in the educational field, where learning and pedagogical practices were managed, and the qualifications of teachers' competence should follow the government rules and legislations. With the interaction between micro level and meso level, it is likely that high-quality learning will take place at the meso level because meso level provides the ways to translate education policies into learning processes (Boeren, 2019; Kaseorg, 2017; Reid, 2018).

Copyright: (C) 2021 the Author(s). This article is an open access article distributed under the terms and conditions of the Creative Commons Attribution (CC-BY) 4.0 license (https://creativecommons.org/licenses/by/4.0/). Published by Al-Kindi Centre for Research and Development, London, United Kingdom. 
At the macro level, Indonesian schools still could not fully enjoy SFH learning because of low internet connectivity because of the inadequate school operational funds to buy data packages (Rasmitadila et al, 2020). One of the biggest challenges in the Indonesian learning system is to uniformize the understanding of schools and teachers in responding to government policies. Thus, it becomes natural if the attitude of schools in responding to policies is very diverse (Abidah et al, 2020).

At the meso level, the ICT competencies of Indonesian teachers were unevenly spread across the regions. The problem of uneven internet access, the disparity of teacher qualifications, and the lack of ICT skills were becoming the weakness in Indonesia's distance learning activity. The COVID-19 outbreak makes new barriers to teachers, such as teachers' capability in using technology, school facilities, difficulties in explaining certain topics through online platforms, limited internet access by students, cost of internet quota, and support from parents (Lie et al, 2020).

In the micro level, another issue being highlighted about online learning lately was there are students that are unfamiliar, unmotivated, and uncertain with virtual classes. These led to absenteeism of students and poor participation which caused anxiety and stress. All in all, the negative perceptions faced by Indonesian students were: (1) limitations to doing practical learning so that learning is more to theory than practice, (2) the difficulty of buying quotas for the internet, (3) features on mobile phones that have limitations, (4) the late assignment because of internet connectivity (Susanto et al, 2021).

The primary objective of this research is to investigate the problems, the solutions, and the impact of macro-level (Indonesian government policies, strategy, and official curricula from public authorities and impacts), meso level (teachers in Indonesian K12 schools), and micro-level (students in Indonesian K12 schools) during COVID-19 pandemic and Indonesian online learning policy. Our research focused on the collective responses by comparing K12 Indonesian schools. We argued that solutions to the COVID19 pandemic and online learning from home that were taken from the macro level (Indonesian government), meso level (Indonesian teacher), and micro level (Indonesian students) could strengthen the perception of the users themselves. We also argued that the problems of distance learning were mostly based on well-structured instructions from macro, meso, and micro levels by calculating the survey data from K-12 Indonesian schools. This study could be used as a tool for the Indonesian government to identify lessons and insights from $\mathrm{K} 12$ schools for online learning responses during the COVID-19 pandemic.

\section{Methodology}

The study employed a qualitative method of the phenomenological approach (Yildirim, 2021) stated that the purpose of the phenomenological approach was to describe a phenomenon from the persons being studied because of person's thoughts, words, and actions were influenced by the past and present, as well as by the physical, psychosocial, and social contexts of the behavior. The researchers attempted to collect and examine the experience of Indonesian teachers and students who conducted online learning from home due to the COVID-19 crisis, for more than 11 months.

The target sample of this study was teachers and students of Indonesian K-12 schools in North Sumatera, namely Pancabudi Medan school, Methodist 12 school, Parulian 1 school, and Primabana school in the form of elementary schools, junior secondary schools, and senior secondary schools. The questionnaire about teachers' perceptions of COVID-19 and online learning was distributed to 73 Indonesian teachers in 4 elementary schools, 77 Indonesian teachers in 4 junior secondary schools, and 122 Indonesian teachers in 4 senior secondary schools. The questionnaire about students' perceptions of COVID-19 and online learning was distributed to 1058 Indonesian students in 4 elementary schools, 1066 Indonesian students in 4 junior secondary schools, and 1864 Indonesian students in 4 senior secondary schools. Their ages range from 7 to 18 . The total sample was 272 Indonesian teachers and 3988 Indonesian students.

This study used three instruments: indirect and participant observations in Zoom recording, materials (schedules and lesson plan), and questionnaires by using a google form. An online survey was the dominant form of survey research in the post-COVID-19 era (Kaden, 2020). The link questionnaire was forwarded to teachers and students. After receiving the link, they clicked that link and fill in the information about the study. The process of open-ended interview was: the participants wrote their opinions according to the statements that the writers were given to figure out the implementation of online learning in COVID-19. The writers chose the opinions randomly from participants (Smoyer et al, 2020).

In the first stage, the researchers conducted a documentation study on Indonesian newspapers and documents relevant to the focus of the research problem, that were the COVID-19 Indonesian education policy (Djalante et al, 2020). Our study used keywords to search such as, 'Indonesian government education in COVID-19 and 'online learning for Indonesian students.' The analysis was based on the writer's interpretation according to Indonesian government policies in Circular Letter. The researchers avoided duplication of paper by cross-checking newspapers independently and dealing with embedded bias so that the findings of this study were robust since the evaluation was taken to minimize the human error (Sivarajah et al, 2017). 
In the second stage, the researchers conducted a preliminary study by asking Indonesian teachers to see whether there were obstacles to school closure, the COVID-19 pandemic, and improvements during online learning from home in those schools. The researcher used an online interview question by using Zoom and WhatsApp video call to gather the data in this study. The first section of the questionnaire was concerned with the demographic characteristics of the respondents (gender, age, educational level, and teaching experience). The second section was concerned with online teaching-related questions in the COVID-19 era. Recorded opinions were transcribed verbatim and analyzed by using a qualitative general inductive approach (Susanto, et al, 2021; Kaden, 2020).

\section{Results}

\subsection{Macro Level: Indonesian Government Responses}

\subsubsection{Education Learning Policy}

Responding to the COVID-19 challenge, the Indonesian Minister of Education and Culture had issued several regulations, often in the form of official circular letters to promote educational equity in Indonesia. The Indonesia education policies were described as follows:

First, the Circular Letter 1 of 2020 on the Policy of Learning Freedom regarding students' graduation stated that: (1) School exams were made by teachers in every educational institution. (2) The implementation of national test scores based on the zone system and was conducted by each regional government. Second, the Circular Letter 2 of 2020 stated that teachers should minimize the lesson plan and always value the education characters in the process of teaching and learning. Third, the Circular Letter 3 of 2020 on the prevention of COVID 19 on the education unit and Number 36962/MPK.A/HK/2020, the government had made several instructions to maintain the effectiveness of distance teaching. Fourth, the Circular Letter 4 of 2020 stated that the Indonesian government canceled the 2020 National exams and would change the national exam in 2021 into the Assessment of Minimum Competency and Survey of Character, which consisted of the ability of language (literacy), the ability of math (numeracy), and character education (Abidah et al, 2020; Djalante et al, 2020). Fifth, the Indonesian government made a zone map for COVID-19 in Indonesia, such as "green" zones, "yellow" zones, "orange" zones, and "red" zones. The risk zone for the Covid-19 transmission was analyzed on a weekly basis showing changes in the risk zone that must be under changes in policies in the field of education. Besides, schools in green zones and yellow zones could carry out face-to-face learning under strict health protocols if received permission from the local Covid-19 handling task force. Sixth, the Minister of Education and Culture issued Ministerial Decree of Minister of Education and Culture Number 719/P/2020 on Guidelines for Emergency Curriculum. The primary concern was every school that undergone a special situation was not required to complete the entire curriculum and teachers could simplify the curriculum independently. The school could conduct a diagnostic assessment to characterize the students' cognitive and noncognitive conditions as the tool for providing an additional lesson for students who had a low grade.

\subsubsection{Free Online Learning Courses}

Indonesian Ministry of Education and Culture had collaborated with technology-based online learning platforms. It allowed teachers and students to access 80,000 learning videos for free such as Ruangguru, Zenius Education, Smart Class, Microsoft Teams, Quipper School, Sekolahmu, Kemendikbud's Learning House (Rumah Belajar Kemendikbud), and many more. These educational online platforms provided educational resources from pre-school to professional levels, such as materials for National Exam, Computer-based Exam (UTBK), and an entrance test (SBMPTN).

\subsubsection{Health Support for Teachers and Students}

The Indonesian Task Force for COVID-19 characterized the three levels of the person who infected the COVID-19: without symptoms (asymptomatic), a person under surveillance (ODP/Orang Dalam Pemantauan), and patient under surveillance (PDP/Pasien Dalam Pengawasan). The test was in the form of isolation, rapid test, and PCR (Djalante et al, 2020).

\subsubsection{Financial Resources for Teachers and Students}

Indonesia's Education and Culture Ministry had announced allowed students to postpone school tuition fee payment and lowering the tuition fee rate by using School Operational Assistance (BOS) and Educational Operational Assistance (BOP). This situation was in line with: (1) the Letter Number 8 and Number 9 of 2020 on Technical Instructions for Regular School Operational Assistance, and (2) the Letter Number 13 of 2020 on Technical Instructions for Non-Physical Special Allocation Fund for Operational Assistance for the Implementation of Early Childhood Education.

\subsection{Meso Level: Teachers' Perceptions of School Closure and the Prevention of COVID-19} 3.2.1 Financial Resources for Teachers and Students

The lack of human interaction and the social-cognitive issue was the most problems when dealing with the prolonged school closures in the COVID-19 era (Armitage \& Nellums, 2021). Table 2 indicated that the problems of school closure for Indonesian teachers were varied, such as interrupting learning (98.53\%), confusion and stress $(98.17 \%)$, low academic progress $(92.27 \%)$, high 
economic costs (100\%), social isolation (100\%), increased dropout rates (68\%), lack of preparation of students' admission to the new education level (70.58\%), disruption of assessment learning (98.16\%), lack of instruction to new teaching strategy (72.79\%), lack of technology and internet access (92.64\%), missing books and basic teaching (89.33\%), and the confusion of communication in teaching and learning (92.64\%).

Table 1. Teachers' Biggest Concerns about School Closure

\begin{tabular}{lll}
\hline Attributes & \multicolumn{2}{c}{ Example Comments } \\
\cline { 2 - 3 } & Percentage & \\
\hline Interrupting learning & $98.53 \%$ & $\begin{array}{l}\text { I felt insecure and exhausted to maintain learning } \\
\text { and minimize inactive students' learning. }\end{array}$
\end{tabular}

\begin{tabular}{|c|c|c|}
\hline Confusion and stress & $98.17 \%$ & $\begin{array}{l}\text { I did not know how to reduce frequent students' } \\
\text { anxiety about online education by using online } \\
\text { platforms. }\end{array}$ \\
\hline Low academic progress & $92.27 \%$ & $\begin{array}{l}\text { Students were learning so much and less } \\
\text { interaction. }\end{array}$ \\
\hline
\end{tabular}

High economic costs $\quad 100 \% \quad$ Learning now was in a difficult situation because of parents' unemployment and you must buy internet quota.

Social isolation $\quad 100 \% \quad$ Teaching project team collaboration in the laboratory could not be interesting from now on.

Increased dropout rates $\quad 68 \% \quad$ The loss of social interaction made students could not catch up with the lesson and declining class participation.

Lack of preparation of students' admission to $70.58 \%$ the new education level

Young people were often unaware of career pathways, so it was all about their education plan ahead, including their skills.

Disruption of assessment learning $\quad 98.16 \%$

I did not understand the procedures for implementing emergency curriculum simplification

Lack of instruction to new teaching strategy $72.79 \%$

It became stressful to completely shift our schedules and academic plans

Lack of technology and internet access $\quad 92.64 \%$

I did not know how to set up Google classroom and keep track of the homework the first time. I was always anxious that I will not be able to deliver lectures because of low internet access.

Missing books and basic teaching $\quad 89.33 \%$

I did not think I could make the same connections and give the same in-the-moment feedback by using the online platform.

The confusion of communication in teaching $92.64 \%$ Many consultations were via phone due to the and learning lack of digital devices.

\subsubsection{Teachers' Perceptions of Emergency Curriculum and Online Learning Resource} Table 2. Teachers' Priorities in Emergency Curriculum

Attributes

Percentage 


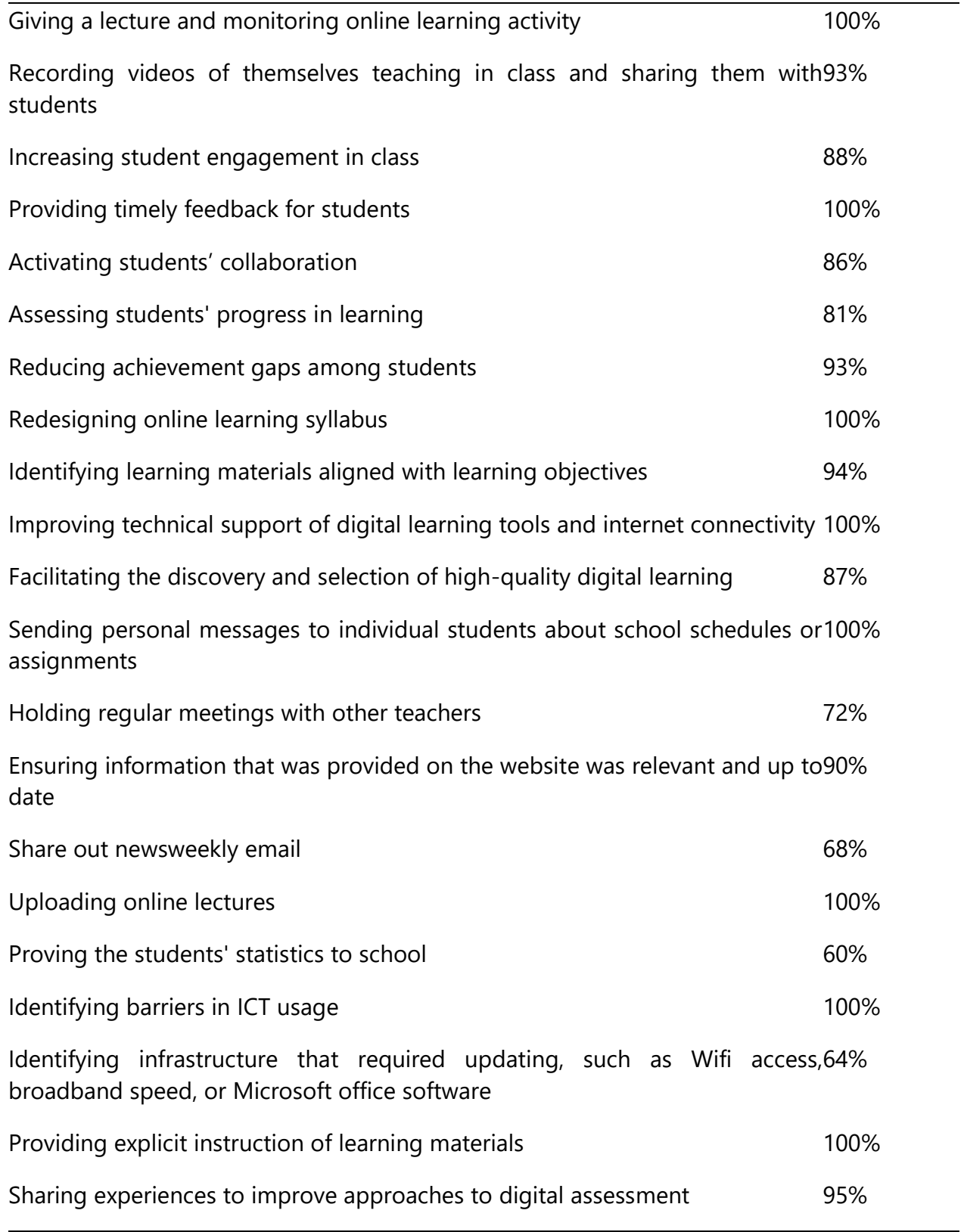

Teachers' digital competence in the COVID-19 era should equip teachers with more ICT specialists skills. The lack of unstructured content versus the abundance of online resources was the main issue in these situations (Konig et al, 2020). Regarding ICT usage and internet connectivity, teacher 1 response was: "I had no real training in online course design." Teacher 2 explained, "I taught grade 2 of elementary school. There was a meeting using Zoom. However, not all children could access it because their parents were still working, some parents were not fluent in using technology applications. Most schools problems associated with the infrastructure such as poor network connectivity, virus attack, and school printers which was not functioning (Ghavifekr and Rosdy, 2015). Regarding the response to the emergency curriculum, teacher 3 shared her experience, "The time allocation was different from normal learning, poor transition to online school was really destroying students' mental health." Teacher 4 noted, "The material was not designed for online use. It was just being adapted to it." Teacher 5 stated, "There were a lot of assignments given to students with little to no instructions." Regarding the virtual online learning activity, teacher 6 stated, "The added bureaucracy from the administrators must be draining." Teacher 7 stated, "What was hardest for students was the lack of interaction leading to a lack of concentration." Teacher 8 stated, "We used to see education gap in the Covid-19 Era because online teaching and learning must be forced and the impact was the students had been negatively affected by the lack of learning service." Regarding the internet connectivity, teacher 9 stated, "The internet connection was slow, making students unable to fully capture the material presented." Teacher 9 stated, "The task load of finding online learning information did not match the area of the teacher's house where internet access was difficult." Regarding the students' objective assessment, teacher 10 stated, "In my opinion, online quizzes 
were nearly impossible to prove the kid was the actual person who was doing the assignments, not the parents." Teacher 11 stated "Students were required to work on the questions in a short time and learned on their own without direct guidance. We were worried about that fact." However, the sudden online learning environment gave different results to teachers' competencies and instructions in using digital technology in meaningful social practices. Distance learning classes could be an alternative learning method because well-constructed materials and discussion forums could increase students' motivation and positive technologysupported environments to address the unique sets of learners, contents, and environments all over the world (Kim, 2020; Talidong et al, 2020).

\subsubsection{Teachers' Perceptions of School Training Program}

Table 3. The Improvement of Teachers' Competence during Online Learning

\begin{tabular}{ll}
\hline Attributes & Percentage \\
\hline Created an effective online syllabus & $96 \%$ \\
Selection of teaching method and selection of online learning platform $93 \%$ & $90 \%$ \\
Analyzed information from online resources & $100 \%$ \\
Pedagogical reflection on IT & $85 \%$ \\
Ability to create a multimedia presentation & $100 \%$ \\
Ability to use assessment in an online format & $100 \%$ \\
Ability of verbal presentation skill & $100 \%$ \\
Ability to play an active role in online discussion & $100 \%$ \\
Ability to encourage students' self-directed learning & $85 \%$ \\
Ability to manage time appropriately & $100 \%$ \\
Ability to access, download, and upload data & $100 \%$ \\
Ability to communicate and collaborate in virtual learning & $100 \%$ \\
Ability to conduct session, record, and post assignments & $72 \%$ \\
Ability to motivate students in a remote environment & $60 \%$ \\
Ability to conduct nonacademic activities in an online environment & \\
\hline Ability to control students' technology mastery & $93 \%$ \\
\hline
\end{tabular}

Regarding the online quiz, teacher 12 stated, "This helped me for daily assessments. So, scores could be directly entered into the form file on Google. If there was a project, there was a video tutorial from Youtube." Regarding the creative online syllabus, teacher 13 stated, "Teachers could match technology with learning materials so that teachers' tasks became simpler and increased collaboration between students."Regarding the motivation for students' learning, teacher 14 stated, "Teachers and students could join the training and saw the results together on the online training website." Regarding the students' self-directed learning, teacher 15 stated, "With videos, the content of learning materials was more focused and away from learning disorders such as jokes."

\subsection{Micro Level: Students' Technology Usage}

Table 4. Students' Positive Effects and Negative Effects of Online Learning 


\begin{tabular}{|c|c|c|c|}
\hline & $\begin{array}{l}\text { Elementary } \\
\text { School } \\
(\mathrm{F}=1058)\end{array}$ & $\begin{array}{l}\text { Junior } \\
\text { Secondary } \\
\text { School } \\
(F=1066)\end{array}$ & $\begin{array}{l}\text { Senior } \\
\text { Secondary } \\
\text { School } \\
(\mathrm{F}=1864)\end{array}$ \\
\hline \multicolumn{4}{|l|}{ The Positive Effects of Online Learning } \\
\hline Visual aids in PowerPoint presentations stimulated my interest & $\begin{array}{l}998 \\
(94 \%)\end{array}$ & $\begin{array}{l}1031 \\
(96 \%)\end{array}$ & 1325 \\
\hline I could control when and where to learn & $\begin{array}{l}783 \\
(74 \%)\end{array}$ & $\begin{array}{l}887 \\
(83 \%)\end{array}$ & $\begin{array}{l}1534 \\
(82 \%)\end{array}$ \\
\hline $\begin{array}{l}\text { I could rate the overall value of the lesson and quality of teaching } \\
\text { by using google forms }\end{array}$ & $(97 \%)$ & $\begin{array}{l}976 \\
(91 \%)\end{array}$ & $\begin{array}{l}1774 \\
(95 \%)\end{array}$ \\
\hline I could explore the website to do my assignments & $\begin{array}{l}654 \\
(61 \%)\end{array}$ & $\begin{array}{l}787 \\
(73 \%)\end{array}$ & $\begin{array}{l}1331 \\
(71 \%)\end{array}$ \\
\hline Convenience sitting at home and taking an online class & $\begin{array}{l}945 \\
(89 \%)\end{array}$ & $\begin{array}{l}766 \\
(71 \%)\end{array}$ & $\begin{array}{l}1297 \\
(69 \%)\end{array}$ \\
\hline $\begin{array}{l}\text { It had taught me about time management and the productivity } \\
\text { of learning. }\end{array}$ & $\begin{array}{l}1021 \\
(96 \%)\end{array}$ & $\begin{array}{l}855 \\
(80 \%)\end{array}$ & $\begin{array}{l}1103 \\
(59 \%)\end{array}$ \\
\hline I could repeat online teaching by watching videos & $\begin{array}{l}1044 \\
(98 \%)\end{array}$ & $\begin{array}{l}1033 \\
(96 \%)\end{array}$ & $\begin{array}{l}1644 \\
(88 \%)\end{array}$ \\
\hline I could share my assignments into a blog or youtube & $\begin{array}{l}985 \\
(93 \%)\end{array}$ & $\begin{array}{l}1022 \\
(95 \%)\end{array}$ & $\begin{array}{l}1543 \\
(82 \%)\end{array}$ \\
\hline $\begin{array}{l}\text { I could improve my research capability by searching materials by } \\
\text { using the website }\end{array}$ & $\begin{array}{l}y 889 \\
(84 \%)\end{array}$ & $\begin{array}{l}845 \\
(79 \%)\end{array}$ & $\begin{array}{l}1202 \\
(64 \%)\end{array}$ \\
\hline I could give emoticons or stickers as a reward to my classmates & $\begin{array}{l}546 \\
(51 \%)\end{array}$ & $\begin{array}{l}744 \\
(69 \%)\end{array}$ & $\begin{array}{l}1366 \\
(73 \%)\end{array}$ \\
\hline Strengthened involvement and cooperation of parents & $\begin{array}{l}552 \\
(52 \%)\end{array}$ & $\begin{array}{l}630 \\
(59 \%)\end{array}$ & $\begin{array}{l}1023 \\
(54 \%)\end{array}$ \\
\hline I had the freedom for my own learning & $\begin{array}{l}765 \\
(72 \%)\end{array}$ & $\begin{array}{l}993 \\
(93 \%)\end{array}$ & $\begin{array}{l}1543 \\
(82 \%)\end{array}$ \\
\hline It encouraged me to learn independently & $\begin{array}{l}883 \\
(83 \%)\end{array}$ & $\begin{array}{l}845 \\
(79 \%)\end{array}$ & $\begin{array}{l}1655 \\
(88 \%)\end{array}$ \\
\hline The Negative Effects of Online Learning & & & \\
\hline Online learning materials were not sited my learning styles & $\begin{array}{l}432 \\
(40 \%)\end{array}$ & $\begin{array}{l}788 \\
(73 \%)\end{array}$ & $\begin{array}{l}1345 \\
(72 \%)\end{array}$ \\
\hline
\end{tabular}




\begin{tabular}{|c|c|c|c|}
\hline Online learning forced me to provide internet quota fees & $\begin{array}{l}1058 \\
(100 \%)\end{array}$ & $\begin{array}{l}1066 \\
(100 \%)\end{array}$ & $\begin{array}{l}1864 \\
(100 \%)\end{array}$ \\
\hline $\begin{array}{l}\text { I was overwhelmed with the amount of information in online } \\
\text { learning }\end{array}$ & $\begin{array}{l}\text { e778 } \\
(73 \%)\end{array}$ & $\begin{array}{l}978 \\
(91 \%)\end{array}$ & $\begin{array}{l}1776 \\
(95 \%)\end{array}$ \\
\hline $\begin{array}{l}\text { I felt anxious or frustrated when I had to take a test or quiz in } \\
\text { online learning }\end{array}$ & $(62 \%)$ & $\begin{array}{l}977 \\
(91 \%)\end{array}$ & $\begin{array}{l}1566 \\
(84 \%)\end{array}$ \\
\hline The interaction was not enough for me & $\begin{array}{l}568 \\
(53 \%)\end{array}$ & $\begin{array}{l}567 \\
(53 \%)\end{array}$ & $\begin{array}{l}1236 \\
(66 \%)\end{array}$ \\
\hline The voice was not audible because of low internet connectivity & $\begin{array}{l}865 \\
(81 \%)\end{array}$ & $\begin{array}{l}778 \\
(72 \%)\end{array}$ & $\begin{array}{l}1233 \\
(66 \%)\end{array}$ \\
\hline I did not have after-school activities anymore & $\begin{array}{l}1022 \\
(96 \%)\end{array}$ & $\begin{array}{l}776 \\
(72 \%)\end{array}$ & $\begin{array}{l}1832 \\
(98 \%)\end{array}$ \\
\hline $\begin{array}{l}\text { I could not interrupt the teacher to ask a question when he o } \\
\text { she was teaching }\end{array}$ & (93\%) & $\begin{array}{l}988 \\
(92 \%)\end{array}$ & $\begin{array}{l}1322 \\
(70 \%)\end{array}$ \\
\hline I had a problem with the explanation of mathematics videos & $\begin{array}{l}988 \\
(93 \%)\end{array}$ & $\begin{array}{l}784 \\
(73 \%)\end{array}$ & $\begin{array}{l}1366 \\
(73 \%)\end{array}$ \\
\hline $\begin{array}{l}\text { Staring at a computer screen for long periods could make me } \\
\text { fatigued and stress }\end{array}$ & $\begin{array}{l}\text { e775 } \\
(73 \%)\end{array}$ & $\begin{array}{l}886 \\
(83 \%)\end{array}$ & $\begin{array}{l}1677 \\
(89 \%)\end{array}$ \\
\hline
\end{tabular}

Most of the online learning support the flexibility of computer connected to a network in order to learn in every time, everywhere, and every purpose of specific conditions (McBrien et al, 2009; Cojocariu et al, 2014). More than 90\% of students agreed that visual aids in PowerPoint presentations stimulated learning interest, re-watched online videos, and shared assignments into a blog or Youtube (see Table 5). Regarding the students' positive effect on online learning, student 1 stated, "I could manage my time to study anywhere as long as there was enough internet connectivity." Student 2 stated, "I could download multiple videos and just enjoyed the learning." Student 3 stated, "Learning from home was just like holidays, I was just prepared my laptop and internet access."

Many teachers recommended unlimited free access websites so students would not pay any fees, only paid the fees of internet access. Besides, teachers should make the selection of appropriate instruction of learning feedback including specific method, objectives, content appropriateness, goal, and ownership (Burdina et al, 2019). Student 4 stated, "I learned so many new things from free online website education." Student 5 stated, "I learned multiple ways of learning based on Kemendikbud's website and it was free." Student 6 stated, "Other highly-trained instructors in Youtube live streaming could give personal feedback in realtime, so we must value the learning." However, more than $90 \%$ of students agreed about the high cost of internet connectivity and after-school activities closure (see Table 5). The high cost of internet connectivity was one of the challenges in the COVID-19 online learning (Noor et al, 2020). Student 7 stated, "My internet access was low but I must fill the questionnaire at the end of the lesson, that was a big problem for me." Student 8 stated, "I could not download videos because of limited internet quota. Besides, my smartphone memory was full because everything was completely online, from studying lesson modules, practice questions, collecting assignments, and discussions with friends." Student 9 stated, "What I could not imagine was the complicated multiplication and division process in mathematics because there was no experience in indirectly learning."

\section{Discussion}

Most Indonesian teachers were unprepared because of the poor organization of materials and technology during the COVID-19 pandemic. Their knowledge and experience with ICT were only relevant for normal classroom situations before the COVID-19 
pandemic (Azhari \& Fajri, 2021). This result was coherent with our findings of the majority of Indonesian teachers (more than 90\%) about the school closure were confusion and stress, interrupted learning, disruption of assessment learning, and lack of technology and internet access (see Table 1). As a result, several policies and education programs had been offered by the Indonesian government to overcome the obstacles faced during online lectures, while still paying attention to health protocols during the pandemic. The difference between the theory and previous studies of our findings showed that online learning systems using digital platforms in Indonesia K12 schools levels could change the face of education to be innovative, more effective, and more attractive. All these findings proved that the transitions of macro, meso, and micro levels in institutional to society-wide level had demonstrated digital pedagogy and students' learning decision-making process changed the organization of Indonesia school management (see Table 2 and Table 3, and Table 4). These strategies in meso level and micro level had been suggested by previous researchers and the researchers themselves after conducting preliminary studies in $\mathrm{K} 12$ schools as the subject of research.

Our study had similarities with previous research examining the use of online learning programs to increase the students' perception of self-efficacy by using technology (Murphy, 2020). Another finding was from (Abidah et al, 2020) stated that a pedagogical and instructional challenge was an important element when adopting online learning activities because it involved technical instruction. Online assisted learning was indeed a new thing for most students in Indonesia, especially those who did not geographically support this effort or the condition of their family's economic background was less supportive of successful learning from home.

\section{Conclusion and Future Work}

The first contribution of this study was to uncover the impacts of the virtual classroom before and after online education training programs. This study revealed some empirical evidence about the effectiveness of online learning based on environmental influences. Whereas other researches focused on the implications of the challenges of ICT in the COVID-19 pandemic, our study offered insight into the satisfaction of online learning and school closure in different perspectives in K12 schools based on the COVID-19 government policies. The second contribution of this study was to conceptualize the barriers and the possible solutions of government (macro), teachers (meso), and students (micro). Each of these three components had a significant role in adopting online education. It impacted the construction of Indonesian education-system-wide manner based on the relation of online education in teacher and students' creativity and the professional development of teachers. The third contribution was the impact of Indonesian government policies (macro) made an innovation about education management in using technology as well as quality support in Indonesian schools.

There were some limitations to our study to provide more new approaches and practical implications for further research. The sample size of our study was not enough to represent the COVID-19 pandemic and online learning education in Indonesia, especially in the health sector. Our suggested policy measures may not be enough to measure the Indonesian government efforts' to prevent COVID-19 cases, especially there was no transparency about health statistics in every school based on Indonesia's geographical conditions. Our study had not adequately covered the Indonesian government's current policy responses in other sectors, only limited to education policy in K12 schools, health sector, and funding sector. Besides that, our study did not report the students' performance and academic progress qualitatively in upcoming years as we did not know how long the COVID-19 pandemic will continue. Hence, future studies should be conducted to fill in the gaps of the previous study. Further study should investigate the effects of online learning in teachers' competency to prove digital transition in the COVID-19 pandemic. Future studies should also investigate the societal impact of rapid online education training programs to reveal the characteristics of successful online teaching and learning activities before and after the COVID-19 pandemic.

Funding: This research received no external funding.

Acknowledgments: The writers would like to acknowledge four schools in North Sumatra, Indonesia as representative of online learning research, especially for the second writer to examine the data during the observation process.

Conflicts of Interest: The authors declare no conflict of interest.

\section{References}

[1] Abidah, A., Hidaayatullaah, H. N., Simamora, R. M., Fehabutar, D., \& Mutakinati, L. (2020). The impact of COVID-19 on Indonesian education and its relation to the philosophy of Merdeka belajar. Studies in Philosophy of Science and Education, 1(1), 38-49.

https://doi.org/10.46627/sipose.v1i1.9 
[2] Armitage, R., \& Nellums, L. B. (2020). Considering inequalities in the school closure response to COVID-19. The Lancet Global Health, 8(5), e644. https://doi.org/10.1016/s2214-109x(20)30116-9

[3] Azhari, B., \& Fajri, I. (2021): Distance learning during the COVID-19 pandemic: School closure in Indonesia. International Journal of Mathematical Education in Science and Technology. https://doi.org/10.1080/0020739X.2021.1875072

[4] Boeren, E. (2019). Understanding sustainable development goal (SDG) 4 on quality education from micro, meso, and macro perspectives. International Review of Education, 65(1), 277-294. https://doi.org/10.1007/s11159-019-09772-7

[5] Burdina, G. M., Krapotkina, I. E., \& Nasyrova, L. G. (2019). Distance learning in elementary school classrooms: An emerging framework for contemporary practice. International Journal of Instruction, 12(1), 1-16. https://doi.org/10.29333/iji.2019.1211a

[6] Cojocariu V. M., Lazar I., Nedeff V., \& Lazar G. (2014). Swot analysis of e-learning educational services from the perspective of their beneficiaries. Procedia-Social and Behavioral Sciences, 116(2014), 1999 2003. https://doi.org/10.1016/j.sbspro.2014.01.510

[7] Djalante, R., Lassa, J., Setiamarga, D., Sudjatma, A., Indrawan, M., Haryanto, B., Mahfud, C., Sinapoy, M. S., Djalante, S., Rafliana, I., Gunawan, L. A., Surtiari, G., \& Warsilah, H. (2020). Review and analysis of current responses to COVID-19 in Indonesia: Period of january to march 2020. Progress in Disaster Science, 6, 100091. https://doi.org/10.1016/j.pdisas.2020.100091

[8] Ghavifekr, S. \& Rosdy, W.A.W. (2015). Teaching and learning with technology: Effectiveness of ICT integration in schools. International Journal of Research in Education and Science (IJRES), 1(2), 175-191.

[9] Kaden, U. (2020). COVID-19 school closure-related changes to the professional life of a k-12 teacher. Education Sciences, 10(6), 1-13. https://doi.org/10.3390/educsci10060165

[10] Kaseorg, M. (2017). Teachers' understanding about education decision-making processes at the macro, meso, and micro levels. New Trends and Issues Proceedings on Humanities and Social Sciences, 4(6), 169-177. https://doi.org/10.18844/prosoc.v4i6.2927

[11] Kim, J. (2020). Learning and teaching online during COVID-19: Experiences of student teachers in an early childhood education practicum. IJEC 52(1), 145-158. https://doi.org/10.1007/s13158-020-00272-6

[12] Konig, J., Jager-Biela, D., \& Glutsch, N. (2020). Adapting to online teaching during COVID-19 school closure: Teacher education and teacher competence effects among early career teachers in Germany. European Journal of Teacher Education, 43(4), 608-622. https://doi.org/10.1080/02619768.2020.1809650

[13] Lie, A., Tamah, S. M., Gozali, I., Triwidayati, K. R., Utami, T. S. D., \& Jemadi, F. (2020). Secondary school language teachers' online learning engagement during the Covid-19 pandemic in Indonesia. Journal of Information Technology Education, 19(1), 803-832. https://doi.org/10.28945/4626

[14] McBrien J. L., Cheng, R., \& Jones, P. (2009). Virtual spaces: Employing a synchronous online classroom to facilitate student engagement in online learning. The International Review of Research in Open and Distributed Learning, 10(3), 1-17. https://files.eric.ed.gov/fulltext/EJ847763.pdf

[15] Noor, S., Isa, F. Md., \& Mazhar, F. F. (2020). Online teaching practices during the COVID-19 pandemic. Educational Process: International Journal, 9(3), 169-184. https://doi.org/10.22521/edupij.2020.93.4

[16] Rasmitadila, Aliyyah, R. R., Rachmadtullah, R., Samsudin, A., Syaodih, E., Nurtanto, M., \& Tambunan, A. R. (2020). The perceptions of primary school teachers of online learning during the COVID-19 pandemic period: A case study in Indonesia. Journal of Ethnic and Cultural Studies, 7(2), 90-109. http://dx.doi.org/10.29333/ejecs/388

[17] Reid T., \& Heck R. H. (2018). Examining variability in language minority students' reading achievement: The influence of school and ethnic background macro contexts. Journal of Education, 198(1), 78-94. https://doi.org/10.1177/0022057418800945

[18] Sivarajah, U., Kamal, M.M., \& Irani, Z., \& Weerakody, V. (2017). Critical analysis of big data challenges and analytical methods. Journal of Business Research, 70(2017), 263-286. http://dx.doi.org/10.1016/j.jbusres.2016.08.0010148-2

[19] Smoyer, A. B., O'Brien, K., \& Rodriguez-Keyes, E. (2020). Lessons learned from COVID-19: Being known in online social work classrooms. International Social Work, 63(5), 651-654. https://doi.org/10.1177/0020872820940021

[20] Susanto, E., Sasongko, R., Kristiawan, M., Nipriansyah, \& Purdiyanto. (2021). Constraints of online learning using google classroom during COVID-19. Education Quarterly Reviews, 4(2), 100-107. https://doi.org/10.31014/aior.1993.04.02.201

[21] Talidong, K. J. B., Toquero, C. M. D., Joy, K., Mae, C., \& Philippine, D. T. (2020). Philippine teachers' practices to deal with anxiety amid COVID-19. Journal of Loss and Trauma, 25(6-7), 573-579. https://doi.org/10.1080/15325024.2020.1759225

[22] Yıldırım, B. (2021). Preschool education in turkey during the COVID-19 pandemic: A phenomenological study. Early Childhood Education Journal. https://doi.org/10.1007/s10643-021-01153-w 